\title{
Analisis Faktor yang Mempengaruhi Loyalitas Perawat di Rumah Sakit
} Tugu Ibu Depok

Analysis on the Influencing Factors of Nurse Loyalty at Tugu Ibu Hospital Depok

${ }^{1}$ Rina Veronica

${ }^{1}$ Institut Kesehatan Indonesia

Email: riena.veronica3@gmail.com

Alamat Korespondensi: Jl. Bawal 1 No.2 Rawamangun, Jakarta Timur

\begin{abstract}
ABSTRAK
Loyalitas karyawan sangat dibutuhkan dalam suatu perusahaan karena merupakan sikap mental karyawan yang ditunjukkan oleh sikap setia terhadap perusahaan. Sebuah perusahaan dengan tingkat loyalitas yang rendah merupakan ujian khusus bagi pengembangan sumber daya manusia karena hal tersebut dapat berdampak langsung pada perusahaan. Perawat merupakan garda terdepan dalam mutu dan kualitas yang diberikan kepada masyarakat dimana perawat selama 24 jam sehari siap siaga menjaga klien demi kesembuhannya. Pelayanan yang baik akan terbentuk dalam pribadi perawat jika perawat tersebut mempunyai komitmen yang baik juga sehingga terbentuk pula loyalitas perawat. Tujuan penelitian untuk mengetahui pengaruh faktor eksternal perawat terhadap loyalitas di RS Tugu Ibu. Desain penelitian ini menggunakan cross sectional. Populasi penelitian sebanyak 90 responden. Aplikasi analisis menggunakan smrtPLS 2.0 dan SPSS 18. Hasil penelitian menunjukkan variabel loyalitas di pengaruhi langsung gaya kepemimpinan $(16,12 \%)$, konflik peran $(13,92 \%)$, iklim kerja $(20,86 \%)$, kepuasan kerja $(12,80 \%)$, dan komitmen organisasi $(18,17 \%)$. Kesimpulandengan demikian iklim kerja paling mempengaruhi di RS Tugu Ibu Depok, dimana iklim kerja kondusif dapat memberikan pengaruh positif terhadap keberhasilan rumah sakit.
\end{abstract}

Kata Kunci: Loyalitas, Komitmen Organisasi, Iklim Kerja, kepuasan Kerja

\begin{abstract}
Loyalty of the employees is needed in a company to show the employee's mental attitude towards the company, which is commonly proved by a loyal attitude. A company with a low level of loyalty is a great challenge towards the development of human resources, as it may bring a direct impact to the company. Nurses are the 'front line' in determining the quality of health services provided to the community. They are ready for 24 hours a day to look after the patients in recovery. Good health services will be accomplished personally if the nurses apply a good commitment, thus the nurse loyalty can be developed. The objective of this research is to realize the effect of nurse external factors towards their loyalty at Tugu Ibu Hospital. This research applies a cross-sectional design. The population of this research includes 90 respondents. This research utilizes smrtPLS 2.0 and SPSS 18 for statistical analysis. The results show that the variable of loyalty is directly affected by the leadership style (16.12\%), role conflict (13.92\%), working climate (20.86\%), job satisfaction (12.80). \%), and organizational commitment (18.17\%). This research concludes that working climate gives the most influence towards the nurse's loyalty at Tugu Ibu Hospital, Depok. Hence, a conducive working climate shall bring a positive influence towards the improvement of nurse loyalty and the hospital achievement.
\end{abstract}

Keywords: loyalty, organizational commitment, working climate, job satisfaction 
Rina Veronica : Analysis on the Influencing Factors of ....

\section{PENDAHULUAN}

Loyalitas merupakan suatu tingkatan sejauh mana seorang karyawan atau individu merasa menjadi bagian dari perusahaan(Runtu, 2013). Setiap individu tergabung didalam perusahaan hendaknya memiliki tingkat loyalitas yang tinggi, sebab keberadaan mereka sebagai alat penggerak perusahaan tidak dapat dipisahkan dengan perasaan yang mereka miliki, dimana penggerak tersebut bisa jadi memilih untuk memegang rahasia perusahaan, sadar untuk membangun perusahaan serta memiliki rasa kepemilikan terhadap tempat bekerjanya ataupun bertindak sebaliknya(Tami, 2015).

Bagi karyawan, loyalitas terhadap perusahaan tidak begitu saja mudah diberikan. Jika perusahaan tidak dapat menghargai karyawan sebagai mana mestinya, diduga karyawan akan berpikir ulang apakah dia akan tetap bekerja di perusahaan itu atau mencari pekerjaan di perusahaan yang lain. Jika begitu keadaannya tidak mungkin perusahaan akan berkembang(Adhian, 2015).

JobsDB Indonesia meluncurkan sebuah survey yang diikuti oleh 2.324 responden di Indonesia dengan bidang pekerjaan dan level karir yang beragam. Hasil survey menunjukkan bahwa sebanyak 80\% responden berkeinginan untuk pindah dalam 12 bulan ke depan. Hal tersebut dikarenakan tidak adanya kepuasan para pekerja dengan sistem dan proses kerja yang dianut oleh perusahaan(Suparyadi, 2015).Perpindahan pegawai di Indonesia tercatat sekitar 10-12\% pegawai melakukan turnover. Hal ini dapat dikatakan menjadi sebuah masalah mengingat proporsi yang baik dalam turnover tidak boleh lebih dari 10\% tiap tahunnya(Ridlo, 2012). Berdasarkan survei yang dilakukan oleh Towers Watson perusahaan jasa professional terkemuka tentang Global Workforce Study 2012 mencakup lebih dari 32.000 karyawan dari 29 negara termasuk Indonesia, menyatakan bahwa hasil survei tersebut ditemukan sekitar 27\% karyawan Indonesia dalam dua tahun mendatang kemungkinan akan meninggalkan pekerjaan saat ini, dan sebanyak $42 \%$ karyawan yakin harus meninggalkan perusahaan tempat mereka bekerja sekarang untuk meningkatkan karirnya di masa depan(Handoko, 2012).

Data turnover perawat di Rumah Sakit Tugu Ibu Depok tahun 2016 mencapai 3\%, data turnover tahun 2017 mencapai 9\%. Kondisi tersebut menunjukkan bahwa ada peningkatan yang signifikan walaupun masih dalam trend positif yaitu kurang dari $10 \%$. Berbagai penelitian dan literatur yang adatelah menunjukkan bahwa keinginan untuk berpindah seseorang tidak bisa lepas dari loyalitas, kepuasan kerja, gaya kepemimpinan, konflik peran, iklim kerja dan komitmen organisasi(Ridlo, 2012). Perputaran keluar masuknya pegawai yang tinggi akan menyita waktu, tenaga dan pikiran juga biaya yang 
tidak sedikit dalam mencari pegawai baru untuk mengisi kekosongan posisi. Apabila karyawan terus berganti maka untuk membangun loyalitas karyawan menjadi sulit dan membutuhkan waktu yang cukup lama karena mereka harus beradaptasi kembali dengan lingkungan tempat mereka bekerja(Mustika, 2016).

Kepemimpinan di era globalisasi akan menghadapi tuntutan yang semakin kompleks. Kondisi demikian menuntut kapabilitas dan ketrampilan pemimpin dalam mengelola perubahan(Suwatno and Juni, 2016).Loyalitas akan muncul jika pemimpin mampu menjaga kenyaman karyawannya dilingkungan kerja. Kenyamanan tersebut merupakan hasil dari kebijakan-kebijakan yang dikeluarkan dan diterpakan pada unit kerja yang dipimpinnya(Carolina, 2017).

Selain itu yang mempengaruhi loyalitas adalah iklim kerja. Iklim kerja menyenangkan akan tercipta, apabila hubungan antar manusia berkembang dengan harmonis. Keadaan iklim yang harmonis ini sangat mendukung terhadap prestasi kerja pegawai. Dengan adanya suasana kerja yang nyaman dan tenang tersebut memungkinkan pegawai untuk bekerja lebih baik(Usman, 2013).

Salah satu penyebab menurunnya loyalitas karyawan adalah kepuasan kerja. Kepuasan kerja merupakan sikap umum terhadap pekerjaan seseorang, selisih antara banyaknya ganjaran yang diterima seorang pegawai dan banyaknya yang mereka yakini apa yang seharusnya mereka terima. Karyawan dengan tingkat kepuasan yang tinggi menunjukkan sikap positif terhadap pekerjaan yang menjadi tanggung jawabnya(Wibowo, 2016).Tujuan penelitian ini adalah untuk mengetahui pengaruh langsung dan tidak langsung serta besarannya faktor yang mempengaruhi loyalitas perawat di Rumah Sakit Tugu Ibu Depok.

\section{METODE}

Jenis penelitian yang digunakan adalah bersifat analitik kuantitatif dengan desain penelitian cross sectional yaitu mengukur variabel eksogen dan endogen disuatu saat secara bersamaan dengan menggunakan pendekatan kuantitatif. Penelitian ini dilakukan di Rumah Sakit Tugu Ibu Depok.

Populasi dalam penelitian adalah seluruh perawat yang ada di Rumah Sakit Tugu Ibu Depok terutama perawat yang masih bekerja di rumah sakit dan sudah menikah pada saat penelitian dilakukan.Jumlah sampel minimal adalah 5xvariabel bebas/indikator dan jumlah sampel maksimal adalah $10 \mathrm{x}$ variabel bebas/indikator. Karena jumlah indikator dalam penelitian ini adalah 15 indikator, maka jumlah sampel minimal adalah 75 perawat 
Rina Veronica : Analysis on the Influencing Factors of ....

dan jumlah sampel minimal adalah 150 perawat. Dalam hal ini peneliti mengambil sampel 90 perawat.

Responden dalam penelitian ini ditentukan dengan melibatkan semua populasi perawat yang ada di ruangan dengan kriteria yaitu: 1). Kriteria inklusi: bersedia menjadi responden, hadir pada saat penelitian, perawat tidak ada halangan seperti cuti atau pendidikan, lama bekerja lebih dari 3 tahun dan latar belakang pendidikannya minimal diploma tiga keperawatan. 2). Kriteria eksklusi: suatu keadaan tertentu dikeluarkan dari kriteria inklusi. Dimana keadaan tersebut adalah responden sakit mendadak, sedang ada cuti atau alasan lain saat sedang penelitian dan responden keluar dari rumah sakit(Nursalam, 2016).

Pada penelitian ini peneliti menyajikan data dalam bentuk tulisan dan tabel sebagai berikut: 1). Naratif, yakni penyajian data hasil penelitian dalam bentuk kalimat. 2). Tabel, yakni suatu penyajian data yang sistematik dari pada data numerik yang tersusun dalam kolom atau jajaran. 3). Gambar, disebut juga diagram data adalah penyajian data dalam bentuk gambar-gambar dengan menggunakan SEM PLS.

Analisis deskriptif dalam penelitian ini digunakan untuk mengidentifikasi gaya kepemimpinan, konflik peran, iklim kerja, komitmen organisasi dan kepuasan kerja terhadap loyalitas perawat, serta memaparkan deskripsi variabel penelitian berdasarkan jawaban setiap kuesioner dengan memberikan skor pada masing-masing jawaban. Adapun langkah-langkahnya sebagai berikut: merancang model structural (Inner Model) dengan menggambarkan hubungan antar variabel laten berdasarkan pada substantive theory. Perancangan model struktural hubungan antar variabel laten didasarkan pada rumusan masalah atau hipotesis penelitian dan merancang (Outer Model).

Uji validitas dan reliabilitas dengan menggunakan Smart Partial Square (PLS), terlihat bahwa nilai factor loading (convergent validity) minimal $>0.5$, discriminant validity minimal memiliki nilai kontruk yang paling tinggi diantara konstruk yang lain dan cross loading menyatakan valid bila hasilnya $>0.5$ dan akar AVE $>0.5$, serta nilai composite reliability $>0.7$ telah memenuhi persyaratan(Sugiyono, 2013).

\section{HASIL}

Data yang didapatkan dianalisis menggunakan analisis univariat, bivariat dan PLS. Pada analisis univariat peneliti mencari data responden berdasarkan karakteristiknya, yaitu: jenis kelamin dan lama bekerja. 
Tabel 1. Distribusi Frekuensi Menurut Karakteristik Responden di RS Tugu Ibu Depok

\begin{tabular}{crrr}
\hline Karakteristik & & Jumlah & Persen \\
\hline \multirow{2}{*}{ Jenis Kelamin } & Laki-Laki & 24 & 26,7 \\
& Perempuan & 66 & 73,3 \\
\multirow{2}{*}{ Lama Bekerja } & 3 -5 Tahun & 30 & 33,3 \\
& $>$ 5 Tahun & 60 & 66,7 \\
\hline
\end{tabular}

Berdasarkan tabel diatas menunjukkan bahwa sebagian besar responden berjenis kelamin perempuan sebanyak 66 (73,3\%) dan berdasarkan lama bekerja memperlihatkan bahwa sebagian besar responden telah bekerja > 5 tahun sebanyak 60 (66,7\%) responden. Setelah didapat karakteristik responden tersebut dikategorikan. Peneliti akan menguji signifikansi melalui pengujian uji chi square.Pada variabel loyalitas rentang responden berada diantara 33-74 mendekati atau tidak jauh dari kisaran teoritisnya pada nilai tertinggi (15- 75) dengan nilai rata rata 62,83 dan standar deviasi 8,95. Hal ini menunjukkan loyalitas berada pada kategori baik. Pada variabel gaya kepemimpinan rentang jawaban responden berada diantara 32-73 mendekati atau tidak jauh dari kisaran teoritisnya pada nilai tertinggi (15 - 75) dengan nilai rata-rata 62,13 dan standar deviasi 10,51. Hal ini mengindikasikan bahwaresponden menganggap kepemimpinan penting dalam mempengaruhi loyalitas.Pada variabel iklim kerja rentang responden berada diantara 33-74 mendekati atau tidak jauh dari kisaran teoritisnya pada nilai tertinggi (1575) dengan nilai rata rata 61,26 dan standar deviasi 10,53. Hal ini menunjukkan bahwa responden menganggap iklim kerja penting dalam mempengaruhi loyalitas. Pada variabel konflik peran rentang responden berada diantara 16-50 mendekati atau tidak jauh dari kisaran teoritisnya pada nilai tertinggi (15- 75) dengan nilai rata-rata 39,97 dan standar deviasi 8,82. Hal ini mengindikasikan bahwa responden menganggap konflik peran mempengaruhi loyalitas.Pada variabel kepuasan kerja kerja rentang responden berada diantara 32-73 mendekati atau tidak jauh dari kisaran teoritisnya pada nilai tertinggi (1575) dengan nilai rata rata 61,08 dan standar deviasi 9,20. Hal ini menunjukkan bahwa responden menganggap kepuasan kerja penting dalam mempengaruhi loyalitas.Pada variabel komitmen organisasi rentang responden berada diantara 34-75 mendekati atau tidak jauh dari kisaran teoritisnya pada nilai tertinggi (15- 75) dengan nilai rata rata 61,11 dan standar deviasi 10,10. Hal ini menunjukkan bahwa responden menganggap komitmen organisasi penting dalam mempengaruhi loyalitas. 
Rina Veronica : Analysis on the Influencing Factors of ....

Hasil faktor loading indikator terhadap masing-masing variabelnya dapat dilihat pada gambar di bawah ini. Berikut output hasil run awal:

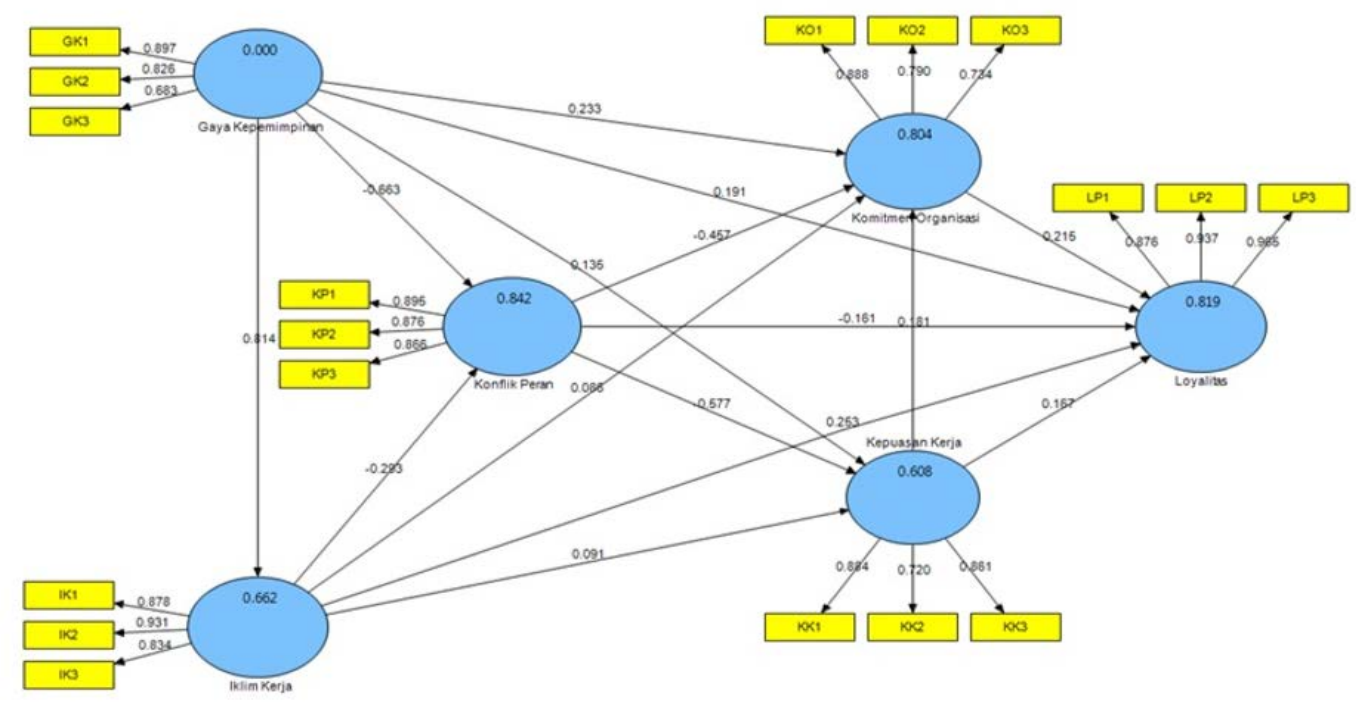

Gambar 1 Output PLS (Loading Factors)

Berdasarkan gambar 1. terlihat bahwa nilai faktor loading telah memenuhi persyaratan yaitu nilai loading faktors lebih besar dari 0,5. Suatu indikator reflektif dinyatakan valid jika mempunyai loadingfaktor di atas 0,5 terhadap konstruk yang dituju berdasarkan pada substantivecontent-nya.Nilai loading faktor tertinggi yaitu pengaruh iklim kerja terhadap loyalitas perawat yaitu seesar 20,86\% dan nilai terendah yaitu pengaruh iklim kerja terhadap kepuasan kerja yaitu sebesar 6,20\%. Nilai paling kecil adalah sebesar 0,683 untuk indikator GK3. Berarti indikator yang dipergunakan dalam penelitian ini adalah valid atau telah memenuhi convergent validity.

Pengukuran dengan membandingkan nilai AVE (Average Variance Extracted) setiap kontruk dengan korelasi antara kontruk dengan kontruk lainnya. Pada tabel evaluasi AVE diatas pada kontruk gaya kepemimpinan sebesar 0,651, iklim kerja sebesar 0,777, kepuasan kerja sebesar 0,680, komitmen organisasi sebesar 0,650 , konflik peran sebesar 0,772 , loyalitas perawat sebesar 0,858 dinyatakan valid karena nilai AVE diatas 0,5, dengan demikian dapat disimpulkan bahwa evaluasi pengukuran model memiliki discriminant validity yang baik. Didapat nilai Cronbach alpha pada semua variabel berkisar 0,700 
hingga 1,000 yang berarti semua indikator handal dalam merefleksikan variabelnya (nilai Cronbach alpha >0,70).

Hasil evaluasi reliabilitas outer model menunjukkan nilai cronbach's alpha semua variabel memiliki nilai lebih besar dari 0,7 berarti variabel gaya kepemimpinan, iklim kerja, kepuasan kerja, komitmen organisasi, konflik peran dan loyalitas, serta dilihat dari composite reliability semua variabel memiliki nilai lebih besar dari 0,7, sehingga dapat dikatakanbahwa kontruk memilikireliabilitas yang baik.



\section{Gambar2. Output PLS Statistik}

Gambar 2 setelah dilakukan bootstrapping untuk mengukur nilai $\mathrm{T}$ statistik dari masing-masing konstruk laten terhadap konstruknya, maka nilai $\mathrm{T}$ statistik dibandingkan dengan nilai $\alpha=0,05(1,96)$. Ketentuannya, apabila nilai $\mathrm{T}$ statistik lebih besar dari nilai $\alpha=0,05(1,96)$, makakonstruk laten tersebut signifikan terhadap konstruknya (Ghozali, 2016).Gambar diatas menyatakan bahwa gaya kepemimpinan berpengaruh positif terhadap iklim kerja 0,813 dan nilai statistik 34,045 dan signifikan pada $\alpha=5 \%$. Nilai T Statistik tersebut berada di nilai kritis $(1,96)$.Untuk gaya kepemimpinan berpengaruh negatif terhadap konflik peran, hasil uji menunjukkan ada pengaruh negatif $-0,663$, sedangkan nilai $\mathrm{T}$ Statistik tersebut berada diatas nilai kritis $(1,96)$. Sedangkan gaya kepemimpinan berpengaruh positif terhadap kepuasan kerja, hasil uji menunjukkan ada pengaruh positif 0,134744 , sedangkan nilai T-Statistik sebesar 3,030590 dan signifikan pada $\alpha=5 \%$, nilai T-Statistik tersebut berada di atas nilai kritis $(1,96)$. 
Gaya kepemimpinan berpengaruh positif terhadap komitmen organisasi, hasil uji menunjukkan ada pengaruh positif 0,232663, sedangkan nilai T-Statistik sebesar 5,398600 dan signifikan pada $\alpha=5 \%$, nilai T-Statistik tersebut berada di atas nilai kritis $(1,96)$. Dan gaya kepemimpinan berpengaruh positif terhadap loyalitas pada perawat, hasil uji menunjukkan ada pengaruh positif 0,190524, sedangkan nilai T-Statistik sebesar 4,597303 dan signifikan pada $\alpha=5 \%$, nilai TStatistik tersebut berada di atas nilai kritis $(1,96)$. Iklim kerja berpengaruh negatif terhadap konflik peran, hasil uji menunjukkan ada pengaruh negatif -0,292553, sedangkan nilai T-Statistik sebesar 7,238197 dan signifikan pada $\alpha=5 \%$, nilai TStatistik tersebut berada di atas nilai kritis $(1,96)$. Sedangkan iklim kerja berpengaruh positif terhadap kepuasan kerja, hasil uji menunjukkan ada pengaruh positif 0,091075, sedangkan nilai T-Statistik sebesar 1,996064 dan signifikan pada $\alpha=5 \%$, nilai T-Statistik tersebut berada di atas nilai kritis $(1,96)$.

Pada iklim kerja berpengaruh positif terhadap komitmen organisasi, hasil uji menunjukkan ada pengaruh positif 0,086065, sedangkan nilai T-Statistik sebesar 2,145283dan signifikan pada $\alpha=5 \%$, nilai T-Statistik tersebut berada di atas nilai kritis (1,96). Sedangkan iklim kerja berpengaruh positif terhadap loyalitas pada perawat, hasil uji menunjukkan ada pengaruh positif 0,253183 , sedangkan nilai T-Statistik sebesar 6,701032dan signifikan pada $\alpha=5 \%$, nilai TStatistik tersebut berada di atas nilai kritis $(1,96)$. Konflik peranberpengaruh negatif terhadap kepuasan kerja, hasil uji menunjukkan ada pengaruh negatif 0,577354, sedangkan nilai T-Statistik sebesar 11,818244dan signifikan pada $\alpha=5 \%$, nilai T-Statistik tersebut berada di atas nilai kritis $(1,96)$. Sedangkan pada konflik peranberpengaruh negatif terhadap komitmen organisasi, hasil uji menunjukkan ada pengaruh negatif -0,457268, sedangkan nilai T-Statistik sebesar 10,081174dan signifikan pada $\alpha=5 \%$, nilai T-Statistik tersebut berada di atas nilai kritis $(1,96)$. Konflik peran berpengaruh negatif terhadap loyalitas pada perawat, hasil uji menunjukkan ada pengaruh negatif -0,161376, sedangkan nilai T-Statistik sebesar 2,986744dan signifikan pada $\alpha=5 \%$, nilai T-Statistik tersebut berada di atas nilai kritis $(1,96)$. Kepuasan kerja berpengaruh positif terhadap komitmen organisasi, hasil uji menunjukkan ada pengaruh positif 0,181064, sedangkan nilai T-Statistik sebesar 7,659470dan signifikan pada $\alpha=5 \%$, nilai TStatistik tersebut berada di atas nilai kritis $(1,96)$. Dan pada kepuasan kerja berpengaruh positif terhadap loyalitas pada perawat, hasil uji menunjukkan ada 
pengaruh positif 0,166739 , sedangkan nilai T-Statistik sebesar 8,910742dan signifikan pada $\alpha=5 \%$, nilai T-Statistik tersebut berada di atas nilai kritis $(1,96)$. Komitmen Organisasi berpengaruh positif terhadap loyalitas pada perawat, hasil uji menunjukkan ada pengaruh positif 0,215482, sedangkan nilai T-Statistik sebesar 5,766547 dan signifikan pada $\alpha=5 \%$, nilai T-Statistik tersebut berada di atas nilai kritis $(1,96)$.

Inner model disebut juga dengan nilai $R$ Square, uji hipotesis T Statistik, pengaruh variabel langsung dan prediktif (nilai $Q$ Square). Gaya kepemimpinan berkontribusi terhadap iklim kerja sebesar 0,661924, gaya kepemimpinan dan iklim kerja berkontribusi terhadap konflik peran sebesar 0,841609, gaya kepemimpinan, iklim kerja dan konflik peran berkontribusi terhadap kepuasan kerja sebesar 0,607552, dan gaya kepemimpinan, iklim kerja, konflik peran dan kepuasan kerja berkontribusi terhadap komitmen organisasi sebesar 0,804280, serta gaya kepemimpinan, iklim kerja, konflik peran, kepuasan kerja dan komitmen organisasi berkontribusi terhadap loyalitas pada perawat sebesar 0,818734 .

Tabel 2.Persentase Pengaruh Antar Variabel Gaya Kepemimpinan, Iklim Kerja, Konflik Peran, Kepuasan Kerja, Komitmen Organisasi, dan Loyalitas pada Perawat di Rumah Sakit Tugu Ibu Depok

\begin{tabular}{lccccccc}
\hline \multicolumn{1}{c}{ Sumber } & $\begin{array}{c}\text { LV } \\
\text { Correlation }\end{array}$ & $\begin{array}{c}\text { Direct } \\
\text { Path }\end{array}$ & $\begin{array}{c}\text { Inderect } \\
\text { Path }\end{array}$ & Total & $\begin{array}{c}\text { Direct } \\
\mathbf{\%}\end{array}$ & $\begin{array}{c}\text { Indirect } \\
\text { \% }\end{array}$ & $\begin{array}{c}\text { Total } \\
\mathbf{\%}\end{array}$ \\
\hline Gaya & 0,846 & 0,191 & 0,656 & 0,846 & 16,12 & 1,38 & 17,50 \\
Kepemimpinan & 0,824 & 0,253 & 0,148 & 0,401 & 20,86 & 0,14 & 21,01 \\
Iklim Kerja & $-0,862$ & $-0,161$ & $-0,217$ & $-0,379$ & 13,92 & 0,17 & 14,09 \\
Konflik Peran & 0,768 & 0,167 & 0,039 & 0,206 & 12,80 & 0,017 & 12,82 \\
Kepuasan Kerja & 0,843 & 0,215 & & 0,215 & 18,17 & & 18,17 \\
Komitmen & Total & & & & 81,87 & 1,71 & 83,59 \\
\hline
\end{tabular}

Tabel 2 menyatakan bahwa gaya kepemimpinan berpengaruh secara langsung dan tidak langsung terhadap loyalitas pada perawat. Hasil uji koefisien parameter antara gaya kepemimpinan terhadap loyalitas pada perawat didapatkan pengaruh langsung sebesar 16,12\%, iklim kerja terhadap loyalitas pada perawat didapatkan pengaruh langsung sebesar 20,86\%, konflik peran terhadap loyalitas pada perawat didapatkan pengaruh langsung sebesar 13,92\%, kepuasan kerja terhadap loyalitas pada perawat didapatkan pengaruh langsung sebesar $12,80 \%$, kepuasan kerja terhadap loyalitas pada 
Rina Veronica : Analysis on the Influencing Factors of ....

perawat didapatkan pengaruh langsung sebesar 18,17\%. Sehingga nilai dari masingmasing pengaruh langsung variabel laten independen tersebut apabila secara bersamasama menunjukkan kesesuaian dengan nilai $R$ Square atau dengan kata lain hal ini menyatakan bahwa variabel gaya kepemimpinan, iklim kerja, konflik peran, kepuasan kerja dan komitmen organisasi mampu menjelaskan variabel loyalitas pada perawat.

\section{PEMBAHASAN}

Berdasarkan hasil uji chi square, diketahui Pvalue $\alpha=5 \%$ (Asymp.Sig) untuk setiap kerakteristik responden lebih besar dari 0,05. Hasil uji tersebut membuktikan bahwa karakteristik responden tidak ada hubungan terhadap variasi jawaban dari variabel loyalitas pada perawat.Pengaruh antar variabel gaya kepemimpinan terhadap loyalitas di dapat dengan nilai $\mathrm{T}$ statistik sebesar 4,597303 > 1,96. Dengan demikian hasil penelitian ini ada pengaruh antara gaya kepemimpinan terhadap loyalitas. Sehingga parameter gaya kepemimpinan terhadap loyalitas dikatakan berpengaruh positif dan signifikan.Hal ini sejalan dengan penelitian Ayu berdasarkan hasil uji T, maka dapat diketahui bahwa variabel bebas yaitu gaya kepemimpinan secara parsial berpengaruh dan memiliki signifikansi positif terhadap variabel terikat yaitu loyalitas karyawan. Hal ini dibuktikan dengan tingkat signifikansi $0.000<0.05$ (Ayu, 2017).

Berdasarkan hasil uji chi square, diketahui Pvalue $\alpha=5 \%$ (Asymp.Sig) untuk setiap kerakteristik responden lebih besar dari 0,05. Hasil uji tersebut membuktikan bahwa karakteristik responden tidak ada hubungan terhadap variasi dari jawaban variabel konflik peran.Hasil pengujian konflik peran terhadap loyalitas didapat dengan nilai $\mathrm{T}$ statistik sebesar 2,986744 > 1,96. Hasil peneliti ada pengaruh antara konflik peran terhadap loyalitas, sehingga parameter konflik peran terhadap loyalitas dikatakan berpengaruh negatif dan signifikan. Sejalan dengan penelitian Tami menunjukkan hasil analisis regresi menghasilkan formulasi $\mathrm{Y}=26$, 009-.639x1 +0,775x2 + 0,393x3 + e. Persamaan tersebut menunjukkan keterangan bahwa konflik peran berpengaruh negatif.Uji $\mathrm{F}$ memperlihatkan hasil terjadinya pengaruh yang signifikan dari variabel konflik peran terhadap variabel loyalitas dengan nilai probabilitas signifikan 0,005< 0,05(Tami, 2015).Menurut peneliti konflik peran mempengaruhi loyalitas karyawan. Makin banyak konflik yang terjadi di perusahaan, makin kecil loyalitas karyawan tersebut terhadap perusahaan.

Berdasarkan hasil uji chi square, diketahui Pvalue $\alpha=5 \%$ (Asymp.Sig) untuk setiap kerakteristik responden lebih besar dari 0,05. Hasil uji tersebut membuktikan bahwa karakteristik responden tidak ada hubungan terhadap variasi dari jawaban variabel 
iklim kerja.Hasil pengujian iklim kerja terhadap loyalitas didapat dengan nilai T statistik sebesar 6,701032 > 1,96. Dengan demikian hasil penelitian ini ada pengaruh antara iklim kerja terhadap loyalitas, sehingga parameter iklim kerja terhadap loyalitas dikatakan berpengaruh positif dan signifikan.Penelitian yang dilakukan oleh Rahma dan Ranu menunjukkan iklim kerja secara parsial berperan positif terhadap loyalitas pegawai di bagian umum sekretariat Daerah Kabupaten Lamongan. Pengujian yang dilakukan dengan uji -T diperoleh hasil koefisien regresi untuk variable iklim kerja adalah 0,236 (tanda positif). Koefisien ini signifikan pada $\alpha=0,05$ karena thitung $>$ ttabel $(2,36>$ 2,021). Itu artinya peran iklim kerja terhadap loyalitas adalah signifikan(Rahmah, A. and Ranu, 2013).Iklim kerja sangat berpengaruh terhadap loyalitas kerja. Pengaruh tersebut memiliki arah hubungan positif, sehingga apabila variabel iklim kerja mengalami peningkatan, maka hal tersebut akan berpengaruh besar terhadap loyalitas dari karyawan tersebut dimana minat pekerjaan seseorang berpengaruh besar terhadap loyalitas pada perusahaan itu sendiri.

Berdasarkan hasil uji chi square, diketahui Pvalue $\alpha=5 \%$ (Asymp.Sig) untuk setiap kerakteristik responden lebih besar dari 0,05. Hasil uji tersebut membuktikan bahwa karakteristik responden tidak ada hubungan terhadap variasi dari jawaban variabel komitmen organisasi.Hasil pengujian komitmen organisasi terhadap loyalitas didapat dengan nilai T statistik sebesar 5,766547 > 1,96. Dengan demikian hasil penelitian ini ada pengaruh antara komitmen organisasi terhadap loyalitas, sehingga parameter komitmen organisasi terhadap loyalitas dikatakan berpengaruh positif dan signifikan.Hasil penelitian Adi bahwa hasil analisis regresi linier berganda diperoleh persamaan: $\mathrm{Y}=3,661+$ 0,220X1 + 0,517 X2 + 0,342 X3. Variabel karakteristik personal, karakteristik pekerjaan dan pengalaman kerja berpengaruh secara bermakna terhadap loyalitas karyawan PT. Garudafood Divisi Biskuit Gresik. Simpulan ini berdasarkan pada hasil uji F dimana F hitung $(14,287)>$ Ftabe1 $(2,9752)$ dan t hitung terletak pada daerah penerimaan yaitu thitung $>$ t tabel Sedangkan variabel karakteristik personal berpengaruh dominan terhadap loyalitas karyawan pada perusahaan PT. Garudafood Divisi Biskuit Gresik karena memiliki nilai determinasi (r2) terbesar yaitu 0,0812 dan dengan nilai t sebesar 1,867(Adi, 2008).Komitmen organisasi sangat berpengaruh terhadap loyalitas karyawan. Penurunan komitmen organisasi akan berpengaruh besar terhadap kepuasan kerja yang tentunya juga akan berpengaruh kepada loyalitas karyawan.

Berdasarkan hasil uji chi square, diketahui Pvalue $\alpha=5 \%$ (Asymp.Sig) untuk setiap kerakteristik responden lebih besar dari 0,05. Hasil uji tersebut membuktikan 
Rina Veronica : Analysis on the Influencing Factors of ....

bahwa karakteristik responden tidak ada hubungan terhadap variasi dari jawaban variabel kepuasan kerja.Hasil pengujian kepuasan kerja terhadap loyalitas didapat dengan nilai $\mathrm{T}$ statistik sebesar 8,910742 > 1,96. Dengan demikian hasil penelitian ini ada pengaruh antara kepuasan kerja terhadap loyalitas, sehingga parameter kepuasan kerja terhadap loyalitas dikatakan berpengaruh positif dan signifikan.Menurut penelitian Kurniawan didapatkan dari uji statistik (Uji T) bahwa variabel kepuasan kerja berpengaruh positif dan signifikan terhadap loyalitas karyawan. Variabel kepuasan kerja memberikan nilai koefisien sebesar 2,997 dengan tingkat signifikansi sebesar 0,004(Kurniawan, 2015).Kepuasan kerja akan mempengaruhi loyalitas karyawan. Selain itu kepuasan kerja karyawan juga dapat dinilai dari seberapa besar perusahaan memberikan feedback positif atas pencapaian hasil pekerjaan karyawan tersebut. Apabila perusahaan tidak mampu memberikan feedback positif (seperti benefit, asuransi, dll), maka akan sangat sulit karyawan tersebut loyal terhadap perusahaan.

Berdasarkan hasil uji chi square, diketahui Pvalue $\alpha=5 \%$ (Asymp.Sig) untuk setiap kerakteristik responden lebih besar dari 0,05. Hasil uji tersebut membuktikan bahwa karakteristik responden tidak ada hubungan terhadap variasi jawaban dari variabel gaya kepemimpinan.Hasil pengujian Gaya Kepemimpinan terhadap Komitmen Organisasi didapat dengan nilai $\mathrm{T}$ statistik sebesar 5,398600 >1,96. Dengan demikian hasil penelitian ini ada pengaruh antara gaya kepemimpinan terhadap komitmen organisasi, sehingga parameter gaya kepemimpinan terhadap komitmen organisasi dikatakan berpengaruh positif dan signifikan.Penelitian yang dilakukan oleh Hendrik bahwa ada pengaruh positif dan signifikan variabel gaya kepemimpinan terhadap komitmen organisasi. Untuk variabel gaya kepemimpinan mempunyai nilai coronbrach alpha sebesar 0.867, sehingga dapat dikatakan reliabel. Nilai sig 0,002. Nilai sig lebih kecil dari nilai probabilitas 0,05, atau nilai 0,002<0,05, maka H1 diterima dan Ho ditolak. Yang memiliki arti bahwa gaya kepemimpinan memiliki pengaruh yang signifikan terhadap komitmen organisasi(Hendrik, 2014).Hasil pengujian konflik peran terhadap Komitmen Organisasi didapat dengan nilai T statistik sebesar 10,081174 > 1,96. Dengan demikian hasil penelitian ini ada pengaruh antara konflik peran terhadap komitmen organisasi, sehingga parameter konflik peran terhadap komitmen organisasi dikatakan berpengaruh negatif dan signifikan.Menurut penelitian dari Ardianto berdasarkan uji statistik yang telah dilakukan, terbukti bahwa konflik peran berpengaruh terhadap komitmen organisasi dengan $\mathrm{R}$ square adalah 0,822 . Sedangkan dari uji $\mathrm{T}$ dapat juga dibuktikan bahwa konflik peran mempunyai korelasi negatif dengan komitmen 
organisasi. Hal tersebut menggambarkan bahwa semakin tinggi tinggat stress kerja akan menurunkan secara signifikan tingkat komitmen organisasi. Sedangkan menurut penelitian (Churiyah, 2007), didapatkan nilai sig. t yang lebih dari 0,05 dan nilai thitung yang lebih kecil dari nilai ttabel menyebabkan Ho diterima artinya bahwa konflik peran berpengaruh negatif terhadap komitmen organisasi(Ardianto, 2013). Konflik peran berpengaruh negatif pada komitmen organisasi. Makin banyak konflik yang terjadi di suatu perusahaan akan sulit untuk seseorang berkomitmen terhadap perusahaan tersebut.Hasil pengujian iklim kerja terhadap komitmen organisasi didapat dengan nilai $\mathrm{T}$ statistik sebesar 2,145283 > 1,96.

Dengan demikian hasil penelitian ini ada pengaruh antara iklim kerja terhadap komitmen organisasi, sehingga parameter konflik peran terhadap komitmen organisasi dikatakan berpengaruh positif dan signifikan.Nilai 0,153 menunjukkan besarnya pengaruh variabel iklim kerja terhadap variabel komitmen organisasi. Nilai sig sebesar 0,006 menunjukkan ada pengaruh signifikan secara parsial dari variabel iklim kerja terhadap komitmen organisasi karena 0,006 < 0,05(Salindeho, 2016).Iklim kerja yang kondusif memungkinkan seseorang untuk bekerja lebih giat dan berkomitmen pada organisasinya atau perusahaannya. Hasil pengujian gaya kepemimpinan terhadap kepuasan kerja didapat dengan nilai $\mathrm{T}$ statistik sebesar 3,030590 > 1,96. Dengan demikian hasil penelitian ini ada pengaruh antara gaya kepemimpinan terhadap kepuasan kerja, sehingga parameter gaya kepemimpinan terhadap kepuasan kerja dikatakan berpengaruh negatif dan signifikan. Hal ini dapat dilihat dari uji t yang menunjukkan bahwa nilai t-hitung variabel gaya kepemimpinan17,741> nilai t-tabel 1,98. Koefisien regresi ini menunjukkan bahwa setiap kenaikan gaya kepemimpinansebesar 1 satuan, maka perubahan kepuasan kerja yang dilihat dari nilai $\mathrm{Y}$ akan bertambah sebesar 0,987satuan dengan asumsi variabel lain dianggap tetap. Dengan demikian, secara parsial gaya kepemimpinanberpengaruh positif dengan tingkat pengaruh yang signifikan terhadap kepuasan kerja padaPT. HimawanPutraMedan(Sinurat. E.J, 2017). Ada hubungan antara gaya kepemimpinan terhadap kepuasan kerja dikarenakan gaya kepemimpinan yang terarah akan memberikan dampak yang baik bagi karyawannya sehingga kepuasan kerja dapat dicapai.

Hasil pengujian konflik peran terhadap kepuasan kerja didapat dengan nilai $\mathrm{T}$ statistik sebesar 11,818244 >1,96. Dengan demikian hasil penelitian ini ada pengaruh antara konflik peran terhadap kepuasan kerja, sehingga parameter konflik peran terhadap kepuasan kerja dikatakan berpengaruh negatif dan signifikan.Hasil pengujian iklim kerja 
Rina Veronica : Analysis on the Influencing Factors of ....

terhadap kepuasan kerja didapat dengan nilai T statistik sebesar 1,996064 > 1,96. Dengan demikian hasil penelitian ini ada pengaruh antara iklim kerja terhadap kepuasan kerja, sehingga parameter iklim kerja terhadap kepuasan kerja dikatakan berpengaruh positif dan signifikan.Hasil pengujian gaya kepemimpinan terhadap konflik peran didapat dengan nilai T Statistik sebesar 17,004294 > 1,96. Dengan demikian hasil penelitian ini ada pengaruh antara gaya kepemimpinan terhadap konflik peran, sehingga parameter gaya kepemimpinan terhadap konflik peran dikatakan berpengaruh negatif dan signifikan.

Berdasarkan hasil pengujian dari Tri menunjukkan bahwa variabel gaya kepemimpinan berpengaruh negatif dan signifikan terhadap konflik peran. Konflik peran dibuktikan dengan nilai koefisien path sebesar 0.019 dan besarnya $p$ value 0,000(Tri, 2007). Ada hubungan antara gaya kepemimpinan dengan konflik peran. Gaya kepemimpinan yang baik akan dierima oleh bawahannya sehingga meminimalkan konflik yang terjadi di rumah sakit bahkan rumah sakit akan terbebas dari konflik peran. Sebaliknya jika gaya kepemimpinan tidak dapat diterima oleh bawahannya maka kemungkinan akan terjadi konflik peran di rumah sakit.Hasil pengujian gaya kepemimpinan terhadap iklim kerja didapat dengan nilai T statistik sebesar 34,045999> 1,96.Hal ini sejalan dengan penelitian Emilia bahwa ada pengaruh positif antara gaya kepemimpinan dengan iklim kerja. Dari pengolahan data yang diperoleh nilai t table pada alpha 0,05 didapat hasil sebesar 1,686. Nilai t hitung untuk variabel efisiensi pada tingkat signifikan 0,019 adalah 2,871. Dengan demikian dapat diketahui bahwa taraf thitung $>\mathrm{t}$ tabel, yaitu 2,701 >1,686 dan taraf signifikansinya 0,019 < 0,05 berarti hipotesis diterima(Emilia, 2011). Ada hubungan antara gaya kepemimpinan dan iklim kerja. Hal tersebut terbukti jika di dalam suatu organisasi/rumah sakit tercipta lingkungan kerja yang kondusif, maka hal tersebut tidak terlepas dari gaya kepemimpinan seseorang yang diterapkan. Hasil pengujian iklim kerja terhadap konflik peran didapat dengan nilai $\mathrm{T}$ statistik sebesar 7,238197 > 1,96. Dengan demikian hasil penelitian ini ada pengaruh antara iklim kerja terhadap konflik peran, sehingga parameter iklim kerja terhadap konflik peran dikatakan berpengaruh negatif dan signifikan.

Menurut penelitian Alfa diperoleh perhitungan $r=-0,626$ dengan sig $=0,000$ ( $p$ $<0,05)$ berarti ada hubungan negatif dan signifikan antara iklim organisasi dengan konflik peran. Hubungan ini menartikan bahwa semakin baik iklim organisasi maka semakin rendah konflik peran yang terjadi(Alfa, 2013). Bahwa ada hubungan antara iklim kerja dengan konflik peran.Hasil pengujian kepusasan kerja terhadap komitmen organisasi didapat dengan nilai $\mathrm{T}$ statistik sebesar 7,659470 > 1,96. Dengan demikian 
hasil penelitian ini ada pengaruh antara kepuasan kerja terhadap komitmen organisasi, sehingga parameter kepuasan kerja terhadap komitmen organisasi dikatakan berpengaruh positif dan signifikan.Pada hasil uji hipotesis dengan menggunakan korelasi product moment dengan nilai signifikansi sebesar 0,000. Nilai tersebut lebih kecil dari nilai signifikansi yang sudah ditentukan yaitu 0,05dan sebesar 79,3\% berpengaruh terhadap karyawan. Hal tersebut menunjukkan variabel kepuasan kerja memiliki hubungan positif dengan variabel komitmen organisasi sebesar 79,3\%(Anugrah, 2014). Ada hubungan antara kepuasan kerja dengan komitmen organisasi dikarenakan jika karyawan tersebut puas tentang sesuatu seperti mendapatkan benefit dan insentif serta promosi untuk pengembangan karirnya maka akan sangat memungkinkan karyawan tersebut berkomitmen lebih terhadap rumah sakit.

\section{SIMPULAN}

Hasil pengujian hipotesis dengan Structural Equation Model (SEM) dengan metode smartPLS didapatkan temuan bahwa variabel loyalitas di RS Tugu Ibu Depok dipengaruhi oleh gaya kepemimpinan, konflik peran, iklim peran, komitmen organisasi dan kepuasan kerja. Dengan demikian, dari temuan tersebut dapat ditarik kesimpulan bahwa iklim kerja yang paling mempengaruhi loyalitas perawat di RS Tugu Ibu Depok. Iklim kerja yang kondusif dapat memberikan pengaruh positif terhadap keberhasilan rumah sakit dalam mencapai tujuannya, sebaliknya iklim kerja yang tidak kondusif dapat menghambat laju dalam mencapai tujuannya. Pelaksanaan iklim kerja yang baik akan mendorong meningkatnya loyalitas perawat.

\section{UCAPAN TERIMAKASIH}

Penulis mengucapkan terimakasih kepada Dr. Syaifuddin Zuhri, MARS, selaku Direktur Rumah Sakit Tugu Ibu Depok yang telah banyak membantu dan memberikan izin penelitiandan penulis juga mengucapkan terimakasih kepada semua pihak yang telah memberikan kritik serta saran sehingga penelitian ini berjalan lancar.

\section{DAFTAR PUSTAKA}

Adhian, N. (2015) Analisis Pengaruh Ketidakamanan Kerja dan Kepuasan Kompensasi Terhadap Kinerja Karyawan (Studi Pada Karyawan Kontrak PT. Bank Rakyat Indonesia Cabang Kramat Pattimura dan Unit Kerjanya. Universitas Indonesia.

Adi, P. (2008) Analisis Pengaruh Komitmen Organisasi Terhadap Loyalitas Karyawan di Perusahaan PT. Garudafood Divisi Biskuit-Gresik. Fakultas Ekonomi Universitas Airlangga.

Alfa, L. R. (2013) Hubungan Iklim Organisasi dengan Konflik Peran Ganda Sebagai Ibu Rumah Tangga dan Pekerja Pada Pegawai Negeri Sipil Wanita di Akademi Militer Magelang. Universitas Kristen Satya Wacana Salatiga. 
Anugrah, M. N. S. (2014) 'Hubungan Antara Kepuasan Kerja Dengan Komitmen Organisasional Karyawan di PT. Sari Warna Asli Garment-Surakarta’, Jupe UNS, Vol.2. No.

Ardianto, N. (2013) 'Pengaruh Konflik Peran dan Ambiguitas Peran Terhadap Komitmen Organisasional dan Kepuasan Kerja Sebagai Variabel Mediator Pada Tenaga Pengajar Sekolah Musik Indonesia di Regional Tengah (Jogja dan Solo)', Jurnal Ilmiah Managemen.

Ayu, S. L. dkk (2017) 'Pengaruh Gaya Kepemimpinan dan Budaya Organisasi Terhadap Loyalitas Karyawan Pada PT. Gici Group Batam’, Jurnal Akuntansi dan Bisnis’, Jurnal Akuntansi dan Bisnis, Vol.7 No.

Carolina, W. S. D. (2017) 'Analisa Pengaruh Gaya Kepemimpinan Terhadap Loyalitas Karyawan Hotel X Bali', Jurnal Hospitality dan Manajemen Jasa, Vol.5 No.2.

Churiyah, M. (2007) 'Pengaruh Konflik Peran (Role conflict) Terhadap Kepuasan Kerja Perawat serta Komitmen Pada Organisasi’, Jurnal Modernisasi, Vol.3 No.1.

Emilia, S. F. dan S. (2011) 'Pengaruh Gaya Kepemimpinan Terhadap Iklim Kerja Organisasi Pada PT. PLN Cabang Solok’', Vol. X No.

Fatayani, S. (2014) Analisis Kepuasan Kerja dalam Meningkatkan Komitmen Organisasi Karyawan di Rumah Sakit Khusus Bedah Rawamangun Jakarta. Universitas Persada Indonesia (YAI).

Ghozali, I. (2016) Aplikasi Analisis Multivariate Dengan Program IBM SPSS 23. Semarang: Badan Penerbit Universitas Diponegoro.

Handoko, T. H. (2012) Manajemen Personalia dan Sumber Daya Manusia. Yogyakarta: BPFE.

Hendrik, M. S. (2014) 'Pengaruh Gaya Kepemimpinan Terhadap Komitmen Organisasional dengan Kepuasan Kerja Sebagai Variabel Intervening Pada PT. Mitra Cimalati di Cilacap', AGORA, Vol.2 No.1.

Kurniawan, H. dkk (2015) ‘Pengaruh Kepuasan Kerja, Motivasi Kerja dan Kedisiplinan’

Mustika, D. I. (2016) 'Pengaruh Iklim Organisasi Terhadap Loyalitas Kerja Karyawan Hotel Benteng Pekanbaru', Jurnal JOM FISIP, Vol.3 No.

Nursalam (2016) Manajemen Keperawatan Aplikasi dalam Praktik Keperawatan Profesional. Jakarta: Salemba Medika.

Rahmah, A. and Ranu, M. E. (2013) 'Peran Budaya Kerja dan Iklim Kerja Terhadap Loyalitas Pegawai Bagian Umum Sekretariat Daerah Kabupaten Lamongan’, Jurnal Administrasi Perkantoran, Vol. 1 No.

Ridlo, I. (2012) Turn Over Karyawan. Surabaya: PH. Movement Publication.

Runtu, J. (2013) 'Whistelblowing Sebagai Ungkapan Loyalitas Karyawan: Peran Employability dan Ke beranian Moral Karyawan, Makalah dalam Konferensi Nasional Ke-6', Makalah dalam Konferensi Nasional Ke-6. Fakultas Bisnis UKWMS.

Salindeho, L. C. (2016) 'Analisis Pengaruh Iklim Kerja Dan Pengembangan Karir Terhadap Komitmen Karir Dengan Kepuasan Kerja Sebagai Variabel Intervening', Jurnal Riset Bisnis dan Manajemen', Jurnal Riset Bisnis dan Manajemen, Vol.4 No.3.

Sinurat. E.J (2017) 'Pengaruh Gaya Kepemimpinan Terhadap Kepuasan Kerja Karyawan Pada PT. Himawan Putra Medan’, Jurnal Ilmiah Methonomi, Vol.3. No.

Sugiyono (2013) Metode Penelitian Pendidikan Pendekatan Kuantitatif, Kualitatif dan $R \& D$. Bandung: Alfabeta.

Suparyadi (2015) Manajemen sumber daya manusia. Yogyakarta: CV Andi Offset.

Suwatno and Juni, D. P. (2016) Manajemen SDM dalam Organisasi Publik dan Bisnis. Bandung: Penerbit Alfabeta.

Tami, M. . (2015) 'Pengaruh Konflik Peran, Kompensasi Finansial dan Kompensasi Nonfinansial Terhadap Loyalitas Karyawan (Studi Pada PT. Aston Graphindo Indonesia)', Jurnal Ekonomi dan Bisnis.

Tri, U. (2007) Pengaruh Gaya Kepemimpinan Terhadap Konflik Peran dan Ketidakjelasan Peran Serta Kinerja Karyawan di Lingkungan Dinas Pendapatan Kota Batam. Universitas Airlangga. 
Usman, H. (2013) 'Manajemen: Teori, Praktik dan Riset Pendidikan', in Vol. 4 Cet. 1 (ed.). Jakarta: Bumi Aksara.

Wibowo (2016) Manajemen Kinerja. Jakarta: PT. Raja Graffindo.

\begin{tabular}{|l|r|}
\hline Submission & 16 Agustus 2020 \\
\hline Review & 02 September 2020 \\
\hline Accepted & 25 September 2020 \\
\hline Publish & 26 Oktober 2020 \\
\hline DOI & 10.29241/jmk.v\%vi\%i.453 \\
\hline Sinta Level & https://sinta.ristekbrin.go.id/journals/detail?id=3576 \\
\hline
\end{tabular}

